\title{
OTITIS MEDIA IN CHILDREN: WHICH PHENOTYPES ARE MOST LINKED TO ALLERGY? A SYSTEMATIC REVIEW
}

\author{
Eugenio De Corso ${ }^{1}$, Elena Cantone ${ }^{2}$, Jacopo Galli ${ }^{3}$, VERONICA SECCIA ${ }^{4}$, DANIELA \\ LUCIDI $^{5}$, TIZIANA DI CESARE ${ }^{6}$, GIANCARLO OTTAVIANO ${ }^{7}$, Bruno Sergi ${ }^{8}$, \\ GAETANO PALUDETTI ${ }^{6}$, and Anna Fetoni ${ }^{3}$ \\ ${ }^{1}$ Policlinico Universitario Agostino Gemelli \\ ${ }^{2}$ University of Naples Federico II School of Medicine and Surgery \\ ${ }^{3}$ Università Cattolica del Sacro Cuore Facoltà di Medicina e Chirurgia \\ ${ }^{4}$ Azienda Ospedaliero Universitaria Pisana \\ ${ }^{5}$ University Hospital Modena \\ ${ }^{6}$ University Hospital Agostino Gemelli \\ ${ }^{7}$ Università degli Studi di Padova \\ ${ }^{8}$ Policlinico A Gemelli
}

October 26, 2020

\begin{abstract}
Background: allergic rhinitis is a common childhood disease responsible for a major impact on quality of life and health care resources. Many hypotheses have been proposed to explain the link between allergy and otitis media, although a definitive mechanism has not been identified yet. One of the major critical points is that authors failed in distinguishing among different phenotypes of middle ear inflammation. This review pointed out evidence from the laboratory and clinical experience to link allergy to different phenotypes of otitis media in children. Methods: we performed a systematic review in accordance with the Preferred Reporting Items for Systematic Review and Meta-Analysis (PRISMA) process. Our search yielded 3010 articles that were finally screened. This resulted in 20 publications of which the full texts included for the qualitative analysis based on different phenotypes of otitis media. Results: clinical evidences and analyses of biomarkers suggested that allergy may be linked to some phenotypes of otitis media and, in particular, to otitis media with effusion and acute re-exacerbations in children with middle ear effusion. It was not possible to perform the analysis for allergy and acute and chronic otitis media because of paucity and heterogeneity of data. Conclusion: Allergy should be considered in the diagnostic work up of different phenotypes of otitis media. Clinicians should evaluate prompt and accurate treatment of allergy in improving outcomes, although futures studies are required to increase evidence supporting that anti-allergy treatment may be effective in the recovery and outcome of otitis media with effusion.
\end{abstract}

\section{INTRODUCTION}

Allergic rhinitis (AR) is the most frequent chronic condition in childhood and adolescence, its prevalence varies from $1.5 \%$ up to $42 \%,{ }^{1,2}$ reaching $8 \%$ in 6-8-year-old children and up to $35 \%$ in 13-14 -year-old children, with a continuous increase in the developed world. ${ }^{3-5}$

Pediatric AR may have a significant impact on global quality of life, including school performance, sleep disorders, and emotional health. ${ }^{2}$ Furthermore, over the years many authors tried to correlate allergy with the onset of the most frequent upper airway disorders in childrenand in particular of otitis media.It has been estimated that more than $75 \%$ of AR children develop concomitant conditions, including conjunctivitis, 
asthma, atopic dermatitis, upper respiratory tract infections (URTI), rhinosinusitis, adeno-tonsillitis, and otitis media, indicating that AR is not an isolated condition, but it is part of a systemic disease,even though conflicting results are frequently reached..$^{6,7}$

$\mathrm{AR}$ is an inflammatory condition of the nasal mucosa provoked by environmental allergens interacting with immunoglobulin (Ig)E in sensitized subjects. Repeated exposure to allergens may lead to long-term changes in systemic and local inflammation, including up-regulation of nasal eosinophils and allergen-specific IgE, increased levels of adhesion molecules in airway mucosa and enhanced systemic response to allergen challenge. ${ }^{8}$ Consequently, it is not surprising that AR has been historically associated with comorbid upper airway diseases,among which otitis media. ${ }^{9}$

The association between AR and otitismedia isstill controversial. However, AR can cause swelling of nasal mucosa resulting in Eustachian tube (ET) dysfunction and subsequently otitis, in particular otitis media with effusion (OME) characterized by inflammation of the mucous membrane with fluid collection in the middle ear in the absence of acute infection. If untreated, OME may be complicated with hearing loss especially conductive type, poor school performance, behavioral problems, and reduced the quality of life. ${ }^{10}$

The aim of the present systematic review was toevaluate clinical and laboratory evidence,linking allergy to different phenotypes of otitis media in children. Allergy in these conditions may be evocated not only as risk, but also as a worsening factor. Poorly controlled AR might exacerbate comorbidities, whereas early diagnosis and its adequate treatment might improve these disorders having a substantial impact on the quality of life of children. ${ }^{8}$

\section{METHODS}

\section{Search strategy}

This systematic review was conducted in accordance with the Preferred Reporting Items for Systematic Review and Meta-Analysis (PRISMA) process to identify published experimental and clinical articles about allergy and otitis media in children. Manuscript were screened primarily by Ovid Medline and EMBASE and from other sources (Pubmed Central, Cochrane review, Web of Science, and Google Scholar) and published from January 2000 to September 2020. Literature searches were performed in September 2020.

We performed two different searches using MeSH-terms. One group of authors focused on experimental studies matching the term as follow: [(Eustachian tube disfunction) OR (middle ear cytokine) OR (middle ear inflammation)] AND [(allergy) OR (allergic rhinitis) OR (atopy) OR (atopic) OR (allergic children)] AND [(children) OR (childhood) OR (pediatric)]. The second group of authors focused onclinical studies, matching the term as follow: [(acute otitis media) OR (chronic otitis media) OR (otitis media with effusion) OR (recurrent acute otitis media) OR (middle ear effusion) OR (chronic suppurative otitis media) OR (otitis)] AND [(allergy) OR (allergic rhinitis) OR (atopy) OR (atopic) OR (allergic children) OR (nonallergic children) OR (immunoglobulin E) OR (immunotherapy) OR (antihistamine) AND (children) OR (childhood) OR (pediatric)].

Study selection

In the first screening authors read the title and abstract of articles selecting those being as inclusive as possible. The abstracts were screened independently by reviewers of the two groups. Any disagreements were resolved by consensus. Inclusion and exclusion criteria were established before the selection of relevant studies. The inclusion criteria were primary research (including descriptive studies, observational studies, randomized trials, and basic science articles), published after January 2000, addressing allergy and otitis media in children. Furthermore, we questioned whether anti-allergy treatment may prevent the occurrence of otitis media or improve its specific management.

We excluded secondary research studies (e.g., review articles or systematic review), case studies, newspaper article, lecture, letter, comment, personal narrative, consensus conference, editorial. Only articles with full text available were included. Additional studies were manually identified from the reference lists of retrieved 
literature. We excluded all the article that did not meet the inclusion criteria or deal directly with the issue investigated. Based on our review was not possible differentiate between atopy or sensitization and allergy. We included only English-language peer-reviewed papers.

\section{RESULTS AND DISCUSSION}

The details of the systematic search performed are shown in figure 1. In total, our search yielded 3010 articles after duplicates removal. We excluded 1169 articles due to time of publication and type of article, then 1841 were finally screened. This resulted 20 publications included in a qualitative analysis. We summarized in tables the included studies per each phenotype classifying evidence using GRADE methodology. No studies were included in a quantitative synthesis (meta-analysis).

\section{Allergy and middle ear inflammation in children}

Based on signs and symptoms,otitismedia $(\mathrm{OM})$ can be subclassified into different phenotypes:acute otitis media (AOM), otitis media with effusion (OME), chronic OME (cOME) and chronic suppurative otitis media (CSOM). AOM is generally characterized by rapid onset of signs and symptoms of inflammation in the middle ear accompanied by middle ear effusion (MEE); OME is defined as MEE without signs and symptoms of acute inflammation. AOM episodes are self-limited, but some children are at high risk for frequently recurring AOM episodes (RAOM) and in a sub-group of patients, MEE may be delayed for months to years and may evolve in cOME. ${ }^{11,12}$ Eventually, CSOM may occur with or without cholesteatoma and clinical history of both conditions can be very similar in children.

There are many predisposing factors for otitis in children, including genetic predisposition, young age, male gender, very low birth-weight, pre-term birth, immature function of the immune system, little or no breastfeeding, upper airway-infections, day-care attendance, older siblings, tobacco smoke exposure, adenoid hypertrophy, craniofacial abnormalities, dysfunction of the ET, use of a pacifier or push-and-pull plastic bottle caps, and allergy. ${ }^{13}$ Among risk factors, the role of allergy has been thoroughly investigated and has been clearly implicated in pathogenesis of OME, whereasmore controversial findingsare available for AOM.

\section{Allergy and $A O M$ or $O M E$}

\section{Physiopathologic theory linking allergy to increased risk of middle ear inflammation.}

Multiple hypotheses may explain the link between allergy and otitis media, even if a definitive mechanism has not been identified. ${ }^{14}$ The "shock organ" hypothesis speculates that the middle ear may act as a shock organ responding to antigen similar to nasal and bronchial mucosa, according to the unified airway theory hypothesizing that the respiratory tract may behave as one integrated unit. The "Eustachian tube dysfunction" theory speculates that allergy may lead to edema of nasal mucosa, muco-ciliary impairment, and ET ostium blockage, reducing middle ear ventilation and continuous negative pressure, and promoting otitis. Eventually, the most recent hypothesis is that ET dysfunction may be related to chronic inflammation of lymphoid tissues such as adenoids with retrograde aspiration of bacteria and nasopharyngeal secretion into the middle ear cavity.

Laboratory Evidence and biomarkers linking allergic inflammation to increased risk of middle ear inflammation.

Several authors have tried to show an association between allergy and middle ear inflammation by animal studies as well as experimental human models. The phenotype more frequently involved in these studies was OME as reported in table 1. The inflammatory substrate observed in atopic OME patients seems to be similar to that of the late phase of allergic response in AR and asthma patients.Several authors ${ }^{15-17}$ have demonstrated a higher percentage of TH-2 mediators, (eosinophils, T-lymphocytes, IL-4 and IL-5), as well as a hyper-expression of major basic protein and eosinophilic cationic protein in the middle ear fluid, adenoid tissue, and middle ear mucosa in atopic versus non-atopic children with OME. Several other cytokines as tumor necrosis factor alfa, IL-1b, IL-13, IL-6, and IL-8 are elevated in middle ear fluid in children with OME. ${ }^{18}$ Smirnova et al. have demonstrated that these cytokines might play a role as molecular regulators 
of middle ear inflammation switching the acute phase of inflammation to the chronic stage $\cdot{ }^{19}$ Furthermore, histologic studies have demonstrated that there is an increased level of IL-4, IL-5, and eosinophils not only in middle ear fluid but also at both ends of the ET suggesting again the possibility of activating an allergic mechanism in sensitized children. ${ }^{20}$ Accordingly, some authors observed a significantly lower rate of neutrophils and IFN-gamma (predominant in TH-1 inflammatory response) in atopic vs non-atopic OME. ${ }^{16}$

Previous authors have demonstrated that allergic inflammation in the ear of children with OME is similar to that of other target organs confirming the hypothesis that ear is part of unified airway. ${ }^{21,}{ }^{22} \mathrm{In}$ addition, animal models demonstrated that middle ear effusion can be preventedby inhibiting allergy cytokines. ${ }^{22}$

Experimental evidence showed that trans-tympanic histamine challenge compromise muco-ciliary clearance and ventilating function of ET in rat models. ${ }^{23}$ In particular, Hardy et al. ${ }^{24}$ demonstrated that late-phase allergy leads to significant ET dysfunction and subsequent formation of effusion by impairing the ventilatory and clearance function of the ET. Furthermore, Pollok et al. ${ }^{25}$ demonstrated that the late-phase allergic inflammatory response and middle ear effusion may be prevented by pre-treatment with soluble interleukin (IL)-4 receptors (sIL-4R) and more modestly with IL-5 antibodies (IL-5Ab).

The most relevant articles included in the qualitative analyses are summarized in table 1 . The majority of articles supports the link between allergy and otitis media with effusion.

\section{Clinical evidence linking allergy to increased risk of middle ear inflammation}

From a clinical point of view, it is extremely important to distinguish among different phenotypes of otitis media, AOM, RAOM and OME. Clinical evidence from the literature seems to be in favor of an association between allergic rhinitis/atopic status and OME; whereas results about a hypothetical correlation with $\mathrm{AOM}$ and RAOM are contradictory and inconclusive because one of the major critical points is that some authors fail to distinguish among the different phenotypes of middle ear inflammation in children (articles included in the qualitative analyses are reported in table 2). Salah et al. did not find evidence linking atopy or allergy to $\mathrm{AOM} / \mathrm{RAOM}^{26}$, whereas other authors ${ }^{10,27,28}$ demonstrated that children with AR had a significantly higher risk of otitis, even if they did not distinguish among different phenotypes of OM. Accordingly, authors ${ }^{29,30}$ demonstrated that atopic children may have a significantly increased risk of recurrent or persistent $\mathrm{OM}$ needing repeated tympanostomy tube insertions without distinguishing between AOM and OME. Finally, in a recent study authors demonstrated that RAOM was significantly associated with turbinate hypertrophy in children suffering from allergic rhinitis. ${ }^{31}$

On the other hands most authors seem to be in agreement with experimental data confirming also a significant clinical association between allergy and OME. Several manuscripts ${ }^{32-35}$ suggested that AR may specifically influence the onset of OME. Authors demonstrated that AR prevalence was notably higher among OME patients than in the controls, with remarkable differences in eosinophil counts and serum IgE concentrations in the allergic rhinitis patients, compared to other OME patients. ${ }^{36}$ Cheng et al. in a metanalysis including cross-sectional and case-controlled studies confirmed that OME and AR are prevalent in pre-school and school-aged children and that allergy is a risk factor for OME. ${ }^{32}$ Roditi et al. interestingly demonstrated that allergic rhinitis was significantly associated to OME even age was demonstrated as an effect modifier of the association; indeed a significant relationship was observed in children 6 years of age and older, whereas there was no significant association in younger children. ${ }^{37}$ Furthermore, studies have documented thatAR patients have a higher risk of ET dysfunction, particularly during childhood, than non-allergic ones. ${ }^{27}$, ${ }^{38}$ Therefore, AR seems to be a common risk factor in children with OME and there is significant hearing loss compared to non-AR children with OME; in addition, the hearing levelimproved significantly with medical therapy. ${ }^{10}$

Recently, Torretta et al. ${ }^{39}$ demonstrated that allergy or atopy were significantly higher in otitis-prone children with OME than in those with simple RAOM: atopy was found in $73 \%$ of the children with both RAOM and OME versus $39.5 \%$ of those with simple RAOM, while allergy was found in $60 \%$ and $36 \%$, respectively. The authors ${ }^{39}$ suggested that children with both RAOM and OMEare clinically different from children with simple RAOM, as they have a more complex clinical presentation that may be sustained by underlying allergy or atopy. Interestingly, in the same manuscript, children with both RAOM and OME were more 
frequently affected by adenoidal hypertrophy $(\mathrm{AH})(\mathrm{p}=0.016)$. This is the second critical point that makes it difficult to analyze data in this regard, since ET dysfunction and AH are frequently associated with OME. Quaranta et al. ${ }^{40}$ analyzed children with $\mathrm{AH}$ showing that $60 \%$ had OME and that AR was rarely present in this group. AH may constitute a concomitant clinical entity associated with allergy that exponentially promotes the development of OME and may be a confounding factor in the analysis. Accordingly, some authors demonstrated that adenoid tissue and middle ear mucosa share the same inflammatory pattern in allergic children affected by OME. ${ }^{33}$

Most relevant clinical articles ${ }^{33-37,39-42}$ investigating specifically association between OME and allergy and included in the qualitative analyses are summarized in table 3.

Does anti-allergy treatment prevent middle ear inflammation?

The large amount of experimental and clinical data supports the hypothesis that treatment of atopy can have a beneficial effect on some phenotype of otitis, and in particular in OME. Accordingly,Mariño-Sánchezet al.supported the concept that AR is associated to a higher severity and duration of OME andthat antiallergy treatment may improve outcomes in OME patients. ${ }^{4}$ However, it is difficult to demonstrate that treatment of allergy can affect OME outcomes due to the contributing factor of ET dysfunction and AH in the pathophysiology of OME.

Several studies have evaluated the role of oral steroids in OME describing a potential benefit ${ }^{43}$, although long term outcomes are not as clearly established as short term ones. ${ }^{44}$ Children treated with intranasal mometasone experienced higher resolution rates of OME compared with control subjects, and the size of the adenoid tissue decreased more in atopic children. ${ }^{45}$ Tracy and Demain ${ }^{46}$ compared the effects of prophylactic antibiotics alone or in combination with intranasal beclomethasone or placebo and demonstrated that subjects in the beclomethasone plus antibiotic group improved more rapidly than those in the antibiotic alone or placebo group.Nevertheless, no differences were seen amongsubjects with and without allergy. Chimona et al. ${ }^{47}$ assessed the role of antihistamines in OME in an animal experimental model, but no clinical efficacy has been demonstrated for antihistamine alone or in association with topical decongestantsin humans ${ }^{48}$, as confirmed by a meta-analysis. ${ }^{49}$

\section{Allergy and CSOM}

An association between CSOM and allergy has long been debated, and only afew studies have been performed. Interestingly, some authors observed elevated $\operatorname{IgE}$ levels in the middle ear secretions of children with CSOM, suggesting that allergy may play a contributory role in pathogenesis of CSOM. ${ }^{50}$

Fliss et al., in a case control study in children, observed that history of acute and recurrent OM, parental history of chronic otitis media, larger families, and more siblings were associated with high risk for CSOM, whereas sex, parental age and education, allergy, sinusitis, and recurrent URTI were not. ${ }^{51}$ There is paucity of data in literature regarding the role of allergy or atopy as a significant risk factor for CSOM in children and it was not possible to perform a qualitative analysis. Additional studies evaluating are strongly required.

\section{Conclusions}

AR is a common disease in childhood in industrialized countries and has a major impact on quality of life and health care resources. Recent studies pointed out main differences between allergic children and adults. For instance, AR in children seems to be more intermittent and severe than in adults, with less symptoms but with a higher number of comorbidities. ${ }^{52}$ Furthermore, children suffering from AR often present additional conditions that may decrease response to medical treatment, worsening QoL. So, AR in children should be considered a disease with a high multimorbidity.

Experimental and clinical evidence strongly supports the existence of an association between allergy and OME, although clear evidence is still debated. Otherwise, the evidence linking atopy or allergy to $\mathrm{AOM} / \mathrm{RAOM}$ or CSOM is poor and contradictory. Further studies are needed, paying particular attention to the inclusion criteria, the methodology of research and, above all, the accurate phenotyping of otitis media. 
From a clinical point of view, children with persistent moderate to severe AR should be screened for otitis media and in particular, OME.We summarized in a practical algorithm our conclusions per phenotype of otitis in order to elucidate when prompt accurate diagnosis and treatment of allergy is recommended (Fig. 2). Reviewing the data about allergy and middle ear inflammation, we concluded that a clear link exists to some phenotypes of middle ear otitis, and in particular OME and acute re-exacerbation in patients with middle ear effusion.

\section{IMPACT STATEMENT}

Improving the understanding of the pathophysiology of allergy and relationship with otitis media is important to develop preventive measures as well as perform adequate monitoring and treatment of children with allergy and otitismedia with effusion,although futures studies are required to increase evidence supporting that antiallergy treatment may improve resolution and outcome of OME. The evidence linking atopy or allergy to other phenotypes is poor and contradictory and further studies are needed, paying particular attention to accurate phenotyping of otitis media.

TABLE1. Laboratory evidence and biomarkers linking allergy to OME.

\begin{tabular}{|c|c|c|c|c|c|c|}
\hline $\begin{array}{l}\text { Author Year } \\
\text { ) ref }\end{array}$ & No. of cases & No. of cases & $\begin{array}{l}\text { Experimental } \\
\text { models }\end{array}$ & Methods & $\begin{array}{l}\text { Relevant } \\
\text { results }\end{array}$ & $\begin{array}{l}\text { Association. } \\
\text { (Level of } \\
\text { evidence) }\end{array}$ \\
\hline $\begin{array}{l}\text { Sobol et al. } \\
2002(15)\end{array}$ & $\mathrm{N}=26$ & $\mathrm{~N}=26$ & $\begin{array}{l}\text { Middle ear } \\
\text { fluid } \\
\text { specimens } \\
\text { collected } \\
\text { during } \\
\text { myringotomy } \\
\text { in OME } \\
\text { patients } \\
\text { (Children). }\end{array}$ & $\begin{array}{l}\text { Fluid } \\
\text { specimens } \\
\text { were assessed } \\
\text { by means of } \\
\text { immunocyto- } \\
\text { chemistry for } \\
\text { T lymphocytes } \\
\text { (CD3), } \\
\text { eosinophils } \\
\text { (major basic } \\
\text { protein), } \\
\text { neutrophils } \\
\text { (elastase), } \\
\text { mast-cells } \\
\text { (tryptase) and } \\
\text { basophils } \\
\text { (BB1). IL-4, } \\
\text { IL-5, and } \\
\text { IFN- } \gamma \text { were } \\
\text { assessed by } \\
\text { using in-situ } \\
\text { hybridization, }\end{array}$ & $\begin{array}{l}\text { Higher } \\
\text { percentage of } \\
\text { eosinophils, } \\
\text { IL-4, IL-5 and } \\
\text { T lymphocytes } \\
\text { in patients } \\
\text { with atopic } \\
\text { OME } \\
\text { compared with } \\
\text { non-atopic } \\
\text { ones. Higher } \\
\text { percentage of } \\
\text { neutrophils } \\
\text { and } \\
\text { INF-gamma in } \\
\text { non-atopic } \\
\text { patients with } \\
\text { OME. }\end{array}$ & Yes (Level $V)$ \\
\hline $\begin{array}{l}\text { Nguyen et al. } \\
2004 \text { (16) }\end{array}$ & $\mathrm{N}=55$ & $\mathrm{~N}=55$ & $\begin{array}{l}\text { Human torus } \\
\text { tubarius and } \\
\text { adenoid tissues } \\
\text { collected } \\
\text { during } \\
\text { adenoidectomy } \\
\text { (children). }\end{array}$ & $\begin{array}{l}\text { Cellular and } \\
\text { cytokine } \\
\text { profiles were } \\
\text { measured by } \\
\text { immunocyto- } \\
\text { chemistry and } \\
\text { in situ } \\
\text { hybridization. }\end{array}$ & $\begin{array}{l}\text { Predominant } \\
\text { Th2 cytokine } \\
\text { expression and } \\
\text { infiltration of } \\
\text { eosinophils in } \\
\text { atopic } \\
\text { patientscom- } \\
\text { pared with the } \\
\text { non-atopic } \\
\text { ones. }\end{array}$ & Yes (Level $V)$ \\
\hline
\end{tabular}




\begin{tabular}{|c|c|c|c|c|c|c|}
\hline $\begin{array}{l}\text { Wright et al. } \\
2000(17)\end{array}$ & $\mathrm{N}=14$ & $\mathrm{~N}=14$ & $\begin{array}{l}\text { Middle ear } \\
\text { biopsy from } \\
\text { children with } \\
\text { persistent } \\
\text { OME. } \\
\text { (children). }\end{array}$ & $\begin{array}{l}\text { Expression of } \\
\text { CD3, majorba- } \\
\text { sicprotein } \\
\text { (immunocyto- } \\
\text { chemistry), } \\
\text { IL-5 mRNA } \\
\text { (in situ } \\
\text { hybridization) } \\
\text { in mucosa of } \\
\text { persistent } \\
\text { OME patients } \\
\text { vs controls. }\end{array}$ & $\begin{array}{l}\text { Predominant } \\
\text { expression of } \\
\text { CD3, major } \\
\text { basic protein, } \\
\text { and IL-5 in } \\
\text { atopic } \\
\text { persistent } \\
\text { OME vs } \\
\text { controls. }\end{array}$ & Yes (Level $V)$ \\
\hline $\begin{array}{l}\text { Downs, et al. } \\
2001(23)\end{array}$ & $\mathrm{N}=13$ & $\mathrm{~N}=13$ & Rat model & $\begin{array}{l}\text { Measure of } \\
\text { mucociliary } \\
\text { clearance and } \\
\text { passive } \\
\text { opening and } \\
\text { closing } \\
\text { pressures of } \\
\text { ET after } \\
\text { challenge with } \\
\text { either trans- } \\
\text { tympanic or } \\
\text { intranasal } \\
\text { histamine }\end{array}$ & $\begin{array}{l}\text { Increase in } \\
\text { mucociliary } \\
\text { clearance } \\
\text { times and } \\
\text { passive } \\
\text { opening and } \\
\text { closing } \\
\text { pressures with } \\
\text { trans- } \\
\text { tympanic } \\
\text { histamine vs } \\
\text { control } \\
\text { solution. }\end{array}$ & Yes (Level $V)$ \\
\hline $\begin{array}{l}\text { Hardy et al. } \\
2001(24)\end{array}$ & $\mathrm{N} / \mathrm{A}$ & $\mathrm{N} / \mathrm{A}$ & $\begin{array}{l}\text { Rat model } \\
\text { Brown Norway } \\
\text { rats were } \\
\text { sensitized to } \\
\text { ovalbumin and } \\
\text { later } \\
\text { challenged } \\
\text { trans- } \\
\text { tympanically. }\end{array}$ & $\begin{array}{l}\text { ET ventilatory } \\
\text { function and } \\
\text { mucociliary } \\
\text { clearance were } \\
\text { assessed } 2,4, \\
8,24,28 \text { - and } \\
32 \text {-hours } \\
\text { post-challenge. }\end{array}$ & $\begin{array}{l}\text { Exposure to } \\
\text { transtympanic } \\
\text { allergen } \\
\text { induces ET } \\
\text { dysfunction } \\
\text { and } \\
\text { subsequent } \\
\text { formation of } \\
\text { effusion and a } \\
\text { decreased } \\
\text { ability to } \\
\text { actively clear } \\
\text { middle ear } \\
\text { pressure in } \\
\text { allergic } \\
\text { animals. }\end{array}$ & Yes (Level $V)$ \\
\hline
\end{tabular}




\begin{tabular}{|c|c|c|c|c|}
\hline $\begin{array}{l}\text { Pollok } 2002 \\
(25)\end{array}$ & $\mathrm{N} / \mathrm{A} \quad \mathrm{N} / \mathrm{A}$ & $\begin{array}{l}\text { Brown-Norway } \\
\text { rats were } \\
\text { sensitized to } \\
\text { ovalbumin } \\
\text { (OVA) and } \\
\text { challenged } \\
\text { trans- } \\
\text { tympanically. }\end{array}$ & $\begin{array}{l}\text { Two groups of } \\
\text { rats received } \\
\text { soluble IL-4 } \\
\text { receptors } \\
\text { (sIL-4R) and } \\
\text { IL-5 } \\
\text { antibodies } \\
\text { (IL-5Ab) } \\
\text { trans- } \\
\text { tympanically } 1 \\
\text { hour before } \\
\text { challenge. }\end{array}$ & $\begin{array}{l}\text { sIL-4R-pre- } \\
\text { treated rats } \\
\text { showed no } \\
\text { significant } \\
\text { changes in } \\
\text { ventilatory or } \\
\text { clearance } \\
\text { functions of } \\
\text { the ET, } \\
\text { whereas } \\
\text { IL-5Ab group } \\
\text { showed } \\
\text { significant late } \\
\text { ventilatory } \\
\text { and clearance } \\
\text { dysfunction as } \\
\text { well as } \\
\text { inflammatory } \\
\text { mucosal } \\
\text { changes. }\end{array}$ \\
\hline
\end{tabular}

OME: otitis media with effusion; ET: Eustachian tube; IL: interleukin.

Table 2.Articles investigating clinical association between allergy and otitismedia.

Clinical evidence linking allergy to risk of middle ear inflammation

\begin{tabular}{|c|c|c|c|c|c|}
\hline Author Year & Type of article & $\mathrm{N}$ (mean age) & Methods & Relevant results & $\begin{array}{l}\text { Association. } \\
\text { (Level of } \\
\text { evidence) }\end{array}$ \\
\hline Byeon, 2019 (27) & $\begin{array}{l}\text { Epidemiologic } \\
\text { observational } \\
\text { study }\end{array}$ & $\begin{array}{l}\mathrm{N}=472(9.6 \mathrm{yr} \pm \\
0.4)\end{array}$ & Survey data & $\begin{array}{l}\text { Children with } \\
\text { AR had twice } \\
\text { significantly } \\
\text { higher risk of } \\
\text { OM. }\end{array}$ & $\begin{array}{l}\text { Yes (Level IV) } \\
\text { No distinction } \\
\text { between AOM } \\
\text { and OME }\end{array}$ \\
\hline $\begin{array}{l}\text { Martines et al. } \\
2016(28)\end{array}$ & $\begin{array}{l}\text { Case-control } \\
\text { study }\end{array}$ & $\begin{array}{l}\mathrm{N}=204 \text { children } \\
\text { and } 204 \text { controls }\end{array}$ & $\begin{array}{l}\text { To investigate } \\
\text { the main risk } \\
\text { factors for AOM } \\
\text { and OME and } \\
\text { their prevalence } \\
\text { in Sicilian } \\
\text { children }\end{array}$ & $\begin{array}{l}\text { Allergy and } \\
\text { urban } \\
\text { localization } \\
\text { increased the } \\
\text { risk of OM in } \\
\text { children exposed } \\
\text { to smoke, } \\
\text { respectively of } \\
166 \% \text { and } 277 \% \text {. }\end{array}$ & $\begin{array}{l}\text { Yes (Level III) } \\
\text { No distinction } \\
\text { between AOM } \\
\text { and OME }\end{array}$ \\
\hline $\begin{array}{l}\text { Salah et al. } 2013 \\
(26)\end{array}$ & $\begin{array}{l}\text { Retrospective } \\
\text { study }\end{array}$ & $\begin{array}{l}\mathrm{N}=340 \text { infants } \\
\text { with } \mathrm{RAOM}\end{array}$ & $\begin{array}{l}\text { To analyze the } \\
\text { risk factors that } \\
\text { are likely to be } \\
\text { responsible for } \\
\text { RAOM in } \\
\text { children. }\end{array}$ & $\begin{array}{l}\text { Authors did not } \\
\text { find a significant } \\
\text { association } \\
\text { between RAOM } \\
\text { and allergy }\end{array}$ & $\begin{array}{l}\text { None (Level IV) } \\
\text { with RAOM }\end{array}$ \\
\hline
\end{tabular}




\begin{tabular}{|c|c|c|c|c|c|}
\hline $\begin{array}{l}\text { Hardani et al. } \\
2020(10)\end{array}$ & $\begin{array}{l}\text { Case-control } \\
\text { study }\end{array}$ & $\begin{array}{l}\mathrm{N}=625 \text { children } \\
(6 \text { months }-7 \\
\text { years })\end{array}$ & $\begin{array}{l}\text { To investigate } \\
\text { the relationship } \\
\text { between the } \\
\text { incidence of } \\
\text { otitis media } \\
\text { (acute, chronic } \\
\text { and with } \\
\text { effusion) and } \\
\text { risk factors. }\end{array}$ & $\begin{array}{l}\text { Allergic rhinitis } \\
\text { was identified as } \\
\text { one of the most } \\
\text { important risk } \\
\text { factors. }\end{array}$ & $\begin{array}{l}\text { Yes (No } \\
\text { distinction } \\
\text { between } \\
\text { phenotypes) }\end{array}$ \\
\hline
\end{tabular}

AR: allergic rhinitis; OM: otitis media; AOM: acute otitis media; OME: otitis media with effusion; RAOM: recurring acute otitis media episodes; AH: adenoid hypertrophy.

Table 3. Articles investigating specifically clinical association between allergy and otitismediawith effusion.

\begin{tabular}{|c|c|c|c|c|c|}
\hline Author Year & Type of article & $N$ (mean age) & Methods & Relevant results & $\begin{array}{l}\text { Association. } \\
\text { (Level } \\
\text { ofevidence) }\end{array}$ \\
\hline $\begin{array}{l}\text { Cheng et al. } \\
2016(32)\end{array}$ & Metanalysis & $\mathrm{N} / \mathrm{A}$ & $\begin{array}{l}\text { Metanalysis } \\
\text { cross-sectional } \\
\text { and } \\
\text { case-controlled } \\
\text { studies }\end{array}$ & $\begin{array}{l}\text { OME and AR } \\
\text { are prevalent in } \\
\text { pre-school and } \\
\text { school-aged } \\
\text { children. The } \\
\text { study suggests } \\
\text { allergy is a risk } \\
\text { factor for OME. }\end{array}$ & Yes (Level I) \\
\hline $\begin{array}{l}\text { Gultekin et al. } \\
2004(33)\end{array}$ & $\begin{array}{l}\text { Epidemiologic } \\
\text { study }\end{array}$ & $\begin{array}{l}\mathrm{N}=1800 \\
\text { school-children }\end{array}$ & $\begin{array}{l}\text { To determine the } \\
\text { impact of } \\
\text { environmental, } \\
\text { epidemiologic } \\
\text { and familial } \\
\text { factors in the } \\
\text { development of } \\
\text { persistent OME }\end{array}$ & $\begin{array}{l}\text { Allergy history } \\
\text { was a } \\
\text { statistically } \\
\text { significant factor } \\
\text { among children } \\
\text { with OME } \\
\text { compared to } \\
\text { normal children. }\end{array}$ & Yes (Level IV) \\
\hline $\begin{array}{l}\text { Kreiner-Møller } \\
2012(34)\end{array}$ & Cohort study. & $\begin{array}{l}\mathrm{N}=291 \text { children } \\
(6 \mathrm{yr})\end{array}$ & $\begin{array}{l}\text { To investigate } \\
\text { the association } \\
\text { between atopic } \\
\text { disease and } \\
\text { OME. }\end{array}$ & $\begin{array}{l}\text { OME was } \\
\text { diagnosed in } \\
39 \% \text { of the } \\
\text { cohort and was } \\
\text { associated with } \\
\mathrm{AR}(\mathrm{OR}=3.36, \\
\mathrm{CI}=1.26-8.96 \\
\mathrm{P}=0.02)\end{array}$ & Yes (Level III) \\
\hline $\begin{array}{l}\text { Kwon et al. } 2013 \\
(35)\end{array}$ & $\begin{array}{l}\text { Case-control } \\
\text { study }\end{array}$ & $\begin{array}{l}\mathrm{N}=370 \text { children } \\
\text { with OME and } \\
100 \text { controls }\end{array}$ & $\begin{array}{l}\text { To assess the } \\
\text { relationship } \\
\text { between OME } \\
\text { and allergic } \\
\text { diseases }\end{array}$ & $\begin{array}{l}\text { The incidence of } \\
\text { AR alone was } \\
\text { significantly } \\
\text { higher in } \\
\text { children with } \\
\text { OME }(33.8 \%) \\
\text { than without } \\
\text { OME }(16.0 \%) \text {; }\end{array}$ & Yes (Level III) \\
\hline
\end{tabular}




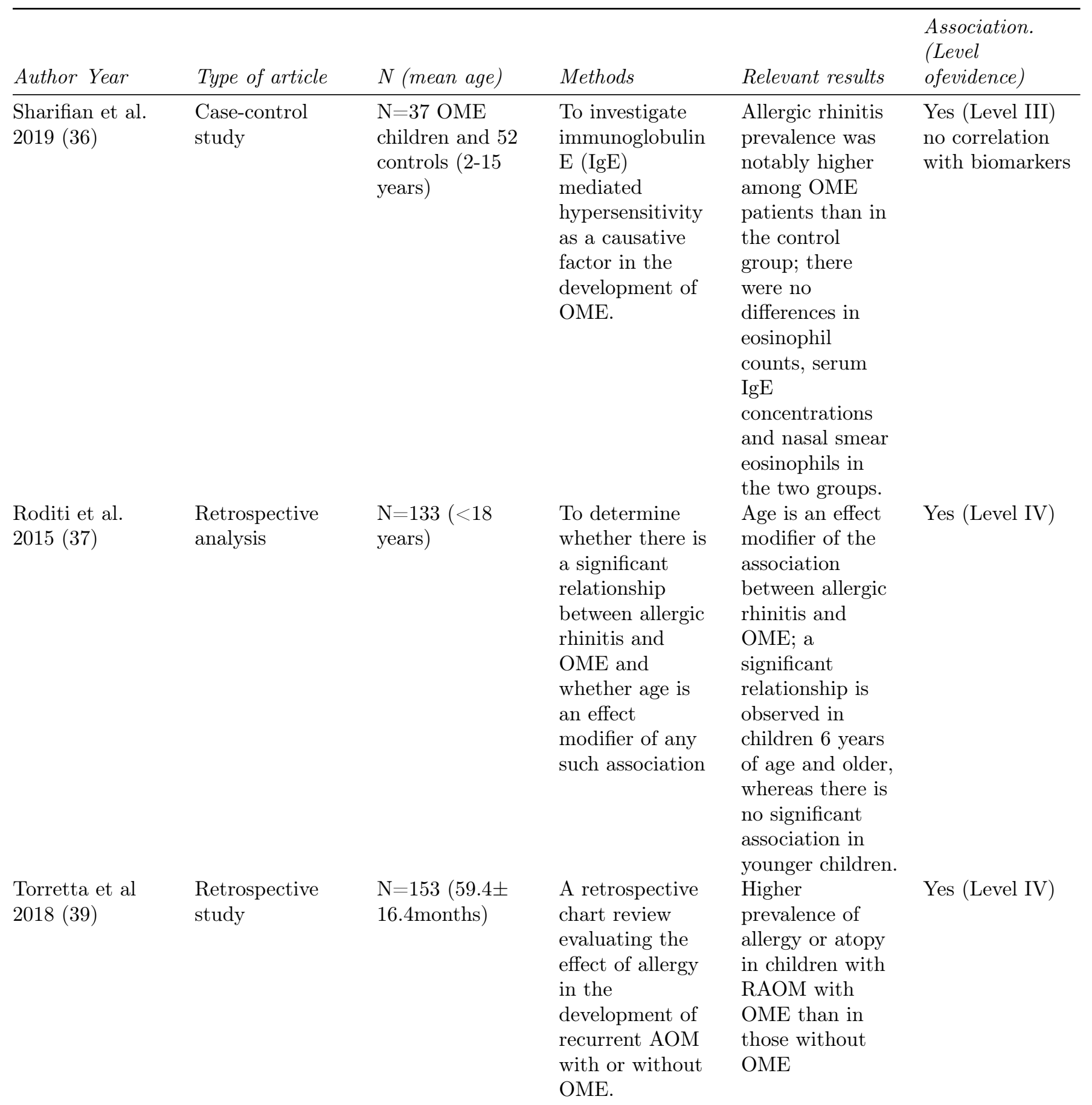




\begin{tabular}{|c|c|c|c|c|c|}
\hline Author Year & Type of article & $N$ (mean age) & Methods & Relevant results & $\begin{array}{l}\text { Association. } \\
\text { (Level } \\
\text { ofevidence) }\end{array}$ \\
\hline $\begin{array}{l}\text { Quaranta et al. } \\
2013(40)\end{array}$ & $\begin{array}{l}\text { Epidemiologic } \\
\text { study }\end{array}$ & $\begin{array}{l}\mathrm{N}=81 \text { children, } \\
\text { Mean age } 6.9 \mathrm{yr} .\end{array}$ & $\begin{array}{l}\text { To evaluate the } \\
\text { role of the } \\
\text { different forms of } \\
\text { chronic rhinitis } \\
\text { in the } \\
\text { pathogenesis } \\
\text { OME in children } \\
\text { with AH. }\end{array}$ & $\begin{array}{l}70 \% \\
\text { of children had a } \\
\text { chronic rhinitis } \\
\text { with AH and } \\
60 \% \text { of them had } \\
\text { OME. Nasal } \\
\text { cytology } \\
\text { together with } \\
\text { Skin prick test } \\
\text { showed that AR } \\
\text { was rarely } \\
\text { present in this } \\
\text { group. }\end{array}$ & Yes (Level IV) \\
\hline $\begin{array}{l}\text { Norhafizh et al. } \\
2020(41)\end{array}$ & $\begin{array}{l}\text { Prospective } \\
\text { cross-sectional } \\
\text { study. }\end{array}$ & $\begin{array}{l}\mathrm{N}=130 \text { children } \\
(4-18 \text { years })\end{array}$ & $\begin{array}{l}\text { To determine the } \\
\text { preva- lence of } \\
\text { allergic rhinitis } \\
\text { in children with } \\
\text { persistent OME }\end{array}$ & $\begin{array}{l}\text { High prevalence } \\
\text { of allergic } \\
\text { rhinitis in } \\
\text { children with } \\
\text { persistent OME } \\
(80.3 \%) \text {; dust } \\
\text { mites was the } \\
\text { most common } \\
\text { allergen.There } \\
\text { was a } \\
\text { statistically } \\
\text { significant } \\
\text { improvement of } \\
\text { the hearing } \\
\text { threshold after } \\
\text { anti-allergy } \\
\text { therapy. }\end{array}$ & Yes (Level II) \\
\hline $\begin{array}{l}\text { Songu et al. } \\
2020(42)\end{array}$ & Cohort study. & $\begin{array}{l}\mathrm{N}=539 \text { patients } \\
\text { undergoing } \\
\text { surgery for } \mathrm{AH}\end{array}$ & $\begin{array}{l}\text { To determine the } \\
\text { most important } \\
\text { risk factors in } \\
\text { the development } \\
\text { of OME in } \\
\text { children with } \\
\text { adenoid } \\
\text { hypertrophy. }\end{array}$ & $\begin{array}{l}\text { Atopy and } \\
\text { allergic rhinitis } \\
\text { resulted as main } \\
\text { risk factors for } \\
\text { OME. }\end{array}$ & Yes (Level III) \\
\hline
\end{tabular}

AR: allergic rhinitis; OM: otitis media; AOM: acute otitis media; OME: otitis media with effusion; RAOM: recurring acute otitis media episodes; AH: adenoid hypertrophy.

\section{Conflict of interest}

The research did not receive any specific grant from founding agency in the public, commercial or nor-forprofit sectors. The authors do not have any conflicts of interest to declare. 


\section{REFERENCES}

1. Seidman MD, Gurgel RK, LinSY et al. Clinical practice guideline: allergic rhinitis. OtolaryngologyHead and Neck Surgery2015;152:S1-S43.

2. Meltzer EO, \& Hamilos DL. Rhinosinusitis diagnosis and management for the clinician: a synopsis of recent consensus guidelines. In Mayo Clinic Proceedings 2011;86:427-443.

3. Asher MI, Montefort S, Björkstén B et al. Worldwide time trends in the prevalence of symptoms of asthma, allergic rhinoconjunctivitis, and eczema in childhood: ISAAC Phases One and Three repeat multicountry cross-sectional surveys. The Lancet2006;368(9537):733-743.

4. Mariño-Sánchez F, Valls-Mateus M, de los Santos G, Plaza AM, Cobeta I, Mullol J. Multimorbidities of pediatric allergic rhinitis. Current allergy and asthma reports 2019 ;19 (2):13.

5. Bousquet J, KhaltaevN, Cruz AA, Denburg J, Fokkens WJ, Togias, Agache, I. Allergic rhinitis and its impact on asthma (ARIA) 2008. Allergy 2008;63:8-160.

6. Wood RA. Pediatric asthma. Jama2002;288(6):745-747.

7. Izquierdo-Domínguez A, Jauregui I, Del Cuvillo A, Montoro J, Dávila I, Sastre J, Valero A L. Allergy rhinitis: similarities and differences between children and adults. Rhinology 2017;55(4):326-31.

8. Borish L. Allergic rhinitis: systemic inflammation and implications for management. Journal of allergy and clinical immunology 2003;112(6):1021-1031.

9. Bousquet J, Van Cauwenberge P, Khaltaev N. Allergic rhinitis and its impact on asthma. Journal of allergy and clinical immunology 2011;108(5): S147-S334.

10. Hardani AK, Esfandabadi FM, Delphi M, Samir MA,Abdollahi FZ. Risk Factors for Otitis Media in Children Referred to Abuzar Hospital in Ahvaz: A Case-Control Study. Cureus 2020;12:8.

11. Casselbrant ML, Mandel EM, DoyleWJ. Information on co-morbidities collected by history is useful for assigning Otitis Media risk to children. International journal of pediatric otorhinolaryngology 2020;85:136-140.

12. Bellussi L, Dhooge I, Downs MP et al. Recent advances in otitis media. 8. Diagnosis and screening.Ann Otol Rhinol Laryngol Suppl 2002 Mar;188:95-101.

13. Zernotti ME, Pawankar R, Ansotegui I et al. Otitis media with effusion and atopy: is there a causal relationship? World Allergy Organization Journal 2017;10(1):37.

14. Döner F, Yariktas M, Demirci M. The role of allergy in recurrent otitis media with effusion. J Investig Allergol Clin Immunol 2004;14(2):154-8.

15. Sobol SE, Taha R, Schloss MD, Mazer BM, Manouikian JJ, Tewfik TL, Hamid Q. TH2 cytokine expression in atopic children with otitis media with effusion. Journal of allergy and clinical immunology 2002;110(1):125-130.

16. Nguyen LH, Manoukian, JJ, Tewfik TL et al. Evidence of allergic inflammation in the middle ear and nasopharynx in atopic children with otitis media with effusion. Journal of otolaryngology 2004;33:(6).

17. Wright ED, Hurst D, Miotto D, Giguere C, Hamid Q. Increased expression of major basic protein (MBP) and interleukin-5 (IL-5) in middle ear biopsy specimens from atopic patients with persistent otitis media with effusion. Otolaryngology-Head and Neck Surgery 2000;123(5):533-538.

18. Zielnik-Jurkiewicz B, Stankiewicz-Szymczak W. Pro-inflammatory interleukins in middle ear effusions from atopic and non-atopic children with chronic otitis media with effusion. European Archives of Oto-Rhino-Laryngology 2016;273(6):1369-1378.

19. SmirnovaMG, Birchall JP,Pearson JP. The immunoregulatory and allergy-associated cytokines in the aetiology of the otitis media with effusion. Mediators of inflammation 2004;13(2:75-88.

20. Juszczak HM,Loftus PA. Role of Allergy in Eustachian Tube Dysfunction. Current Allergy and Asthma Reports 2020;20(10):1-10.

21. Hurst DS, Denne CM. The Relation of Allergy to Eustachian Tube Dysfunction and the Subsequent Need for Insertion of Pressure Equalization Tubes. Ear, Nose \& Throat Journal 2020;22:0145561320918805.

22. Luong A, Roland PS. The link between allergic rhinitis and chronic otitis media with effusion in atopic 
patients. Otolaryngologic Clinics of North America 2008;41(2):311-323.

23. Downs BW, ButehornHF, Prazma J, Rose AS, Stamat JC, Pillsbury III HC. Action of histamine on eustachian tube function. Otolaryngology-Head and Neck Surgery 2001;124(4):414-420.

24. Hardy SM, Heavner SB, White DR, Mcqueen CT, Prazma J, Pillsbury HC. Late-phase allergy and eustachian tube dysfunction. Otolaryngology—Head and Neck Surgery 2001;125(4):339-345.

25. Pollock HW, Ebert CS, Dubin MG, White DR, Prazma J, Pillsbury III HC. The role of soluble interleukin-4 receptor and interleukin-5 antibody in preventing late-phase allergy-induced eustachian tube dysfunction. Otolaryngology - Head and Neck Surgery 2002;127(3):169-176.

26. Salah M, Abdel-Aziz M, Al-Farok A,Jebrini A. Recurrent acute otitis media in infants: analysis of risk factors. International journal of pediatric otorhinolaryngology 2013; 77(10):1665-1669.

27. Byeon $\mathrm{H}$. The association between allergic rhinitis and otitis media: A national representative sample of in South Korean children. Scientific reports 20019;9(1):1-7.

28. Martines F, Salvago P, Ferrara S, Messina G, Mucia M, Plescia F, Sireci F. Factors influencing the development of otitis media among Sicilian children affected by upper respiratory tract infections. Brazilian journal of otorhinolaryngology 2016;82(2):215-222.

29. Juhn YJ,Wi CI. What does tympanostomy tube placement in children teach us about the association between atopic conditions and otitis media? Current allergy and asthma reports 2014;14(7):447.

30. Marchica CL, Pitaro J,Daniel SJ. Recurrent tube insertion for chronic otitis media with effusion in children over 6 years. International journal of pediatric otorhinolaryngology 2013;77(2):252-255.

31. Ciprandi G, Tosca MA, Gallo F, Passali GC,Ameli F. Turbinate hypertrophy in children with allergic rhinitis: clinical relevance. Acta Bio-medica: Atenei Parmensis;2020; 9(1-S):43-47.

32. Cheng X, Sheng H, Ma R et al. Allergic rhinitis and allergy are risk factors for otitis media with effusion: A meta-analysis. Allergologia et immunopathologia 2017;45(1): 25-32.

33. Gultekin E, Develioğlu ÖN, Yener M, Ozdemir I, Külekçi M. Prevalence and risk factors for persistent otitis media with effusion in primary school children in Istanbul, Turkey. Auris Nasus Larynx 2010;37(2):145-149.

34. Kreiner-Moller E, Chawes B LK, Caye-Thomasen P, Bonnelykke K, Bisgaard H. Allergic rhinitis is associated with otitis media with effusion: a birth cohort study. Clinical \& Experimental Allergy 2012;42(11):1615-1620.

35. Kwon C, Lee HY, Kim MG, BooSH, Yeo SG. Allergic diseases in children with otitis media with effusion. International journal of pediatric otorhinolaryngology 2013;77(2):158-161.

36. Sharifian MR, Mahmoudi M, Pourmomenarabi B, Keramati MR. Correlation between allergic rhinitis and otitis media with effusion. Iranian journal of otorhinolaryngology 2019;31(105):209.

37. Roditi, RE, Veling, M,Shin JJ. Age: an effect modifier of the association between allergic rhinitis and otitis media with effusion. The Laryngoscope 2016;126(7):1687-1692.

38. Lazo-Saenz JG, Galvan-Aguilera AA, Martinez-Ordaz VA, Velasco-RodriguezVM, Nieves-Renteria A, Rincon-Castaneda C. Eustachian tube dysfunction in allergic rhinitis. Otolaryngology-Head and Neck Surgery 2005;132(4):626-629.

39. Torretta S, Pignataro L, Carioli D, Ibba T, Folino F, Rosazza C, Fattizio M, Marchisio P. Phenotype Profiling and Allergy in Otitis-Prone Children. Frontiers in pediatrics2018;6:383.

40. Quaranta N, Milella C, Iannuzzi L, Gelardi, M. A study of the role of different forms of chronic rhinitis in the development of otitis media with effusion in children affected by adenoid hypertrophy. International journal of pediatric otorhinolaryngology 2013;77(12):1980-1983.

41. Norhafizah S, Salina H, Goh BS. Prevalence of allergic rhinitis in children with otitis media with effusion. Eur Ann Allergy Clin Immunol 2020;52(3):121-130.

42. Songu M, Islek A, Imre A, Aslan H, Aladag I, Pinar E, Oncel S. Risk factors for otitis media with effusion in children with adenoid hypertrophy. Acta Otorhinolaryngol Ital2020;40(2):133-137.

43. Lack G, Caulfield H, Penagos M. The link between otitis media with effusion and allergy: a potential role for intranasal corticosteroids. Pediatric allergy and immunology 2011;22(3):258-266.

44. Butler CC, van der Voort JH. Steroids for otitis media with effusion: a systematic review. Archives of pediatrics \& adolescent medicine 2001;155(6):641-647. 
45. Cengel S, AkyolMU. The role of topical nasal steroids in the treatment of children with otitis media with effusion and/or adenoid hypertrophy. International journal of pediatric otorhinolaryngology 2006;70(4):639-645.

46. Tracy JM, Demain JG, HoffmanKM, Goetz DW. Intranasal beclomethasone as an adjunct to treatment of chronic middle ear effusion. Annals of Allergy, Asthma \& Immunology 1998;80(2):198-206.

47. Chimona TS, Panayiotides JG, Papadakis CE, Helidonis ES, Velegrakis GA. Antihistamine effects on experimental middle ear inflammatory model. European archives of oto-rhino-laryngology 2008;265(8):899-905.

48. Griffin G, Flynn CA, Bailey RE, Schultz JK. Antihistamines and/or decongestants for otitis media with effusion (OME) in children. Cochrane Database of Systematic Reviews2011 Sep 7;2011(9):CD003423.

49. Roditi RE, Caradonna DS,Shin JJ. The Proposed Usage of Intranasal Steroids and Antihistamines for Otitis Media with Effusion. Current allergy and asthma reports 2009;19(10):47.

50. Lasisi AO, Arinola OG, Olayemi O. Role of elevated immunoglobulin E levels in suppurative otitis media. Ann Trop Paediatr 2008;28(2):123-7.

51. Fliss DM, Shoham I, Leiberman A, Dagan R. Chronic suppurative otitis media without cholesteatoma in children in Southern Israel: Incidence and risk factors. Pediatric Infectious Disease Journal 1991:895899.

52. De Corso E, Lucidi D, Cantone E, Ottaviano G, Di Cesare T, Seccia V, Paludetti G, Galli J.Clinical Evidence and Biomarkers Linking Allergy and Acute or Chronic Rhinosinusitis in Children: a Systematic Review.Curr Allergy Asthma Rep 2020;5;20(11):68.

Figure Legends

Figure 1. Flowchart of article search and selection.

Figure 2: Practical algorithm based on different phenotypes of otitis in children.

Abbreviations: OME: otitis media with effusion; AOM: acute otitis media; RAOM: recurrent acute otitis media; CSOM: chronic suppurative otitis media. 


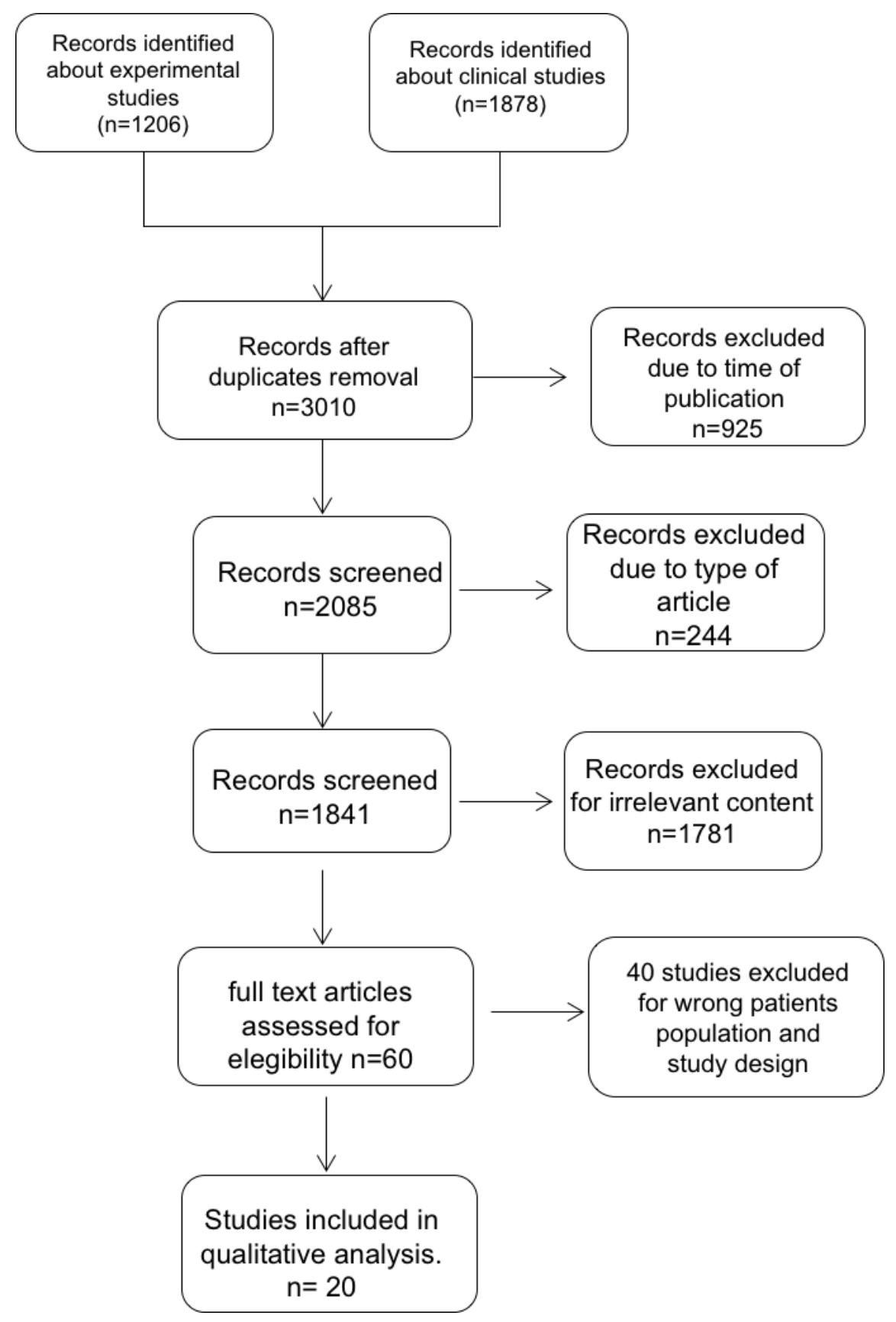




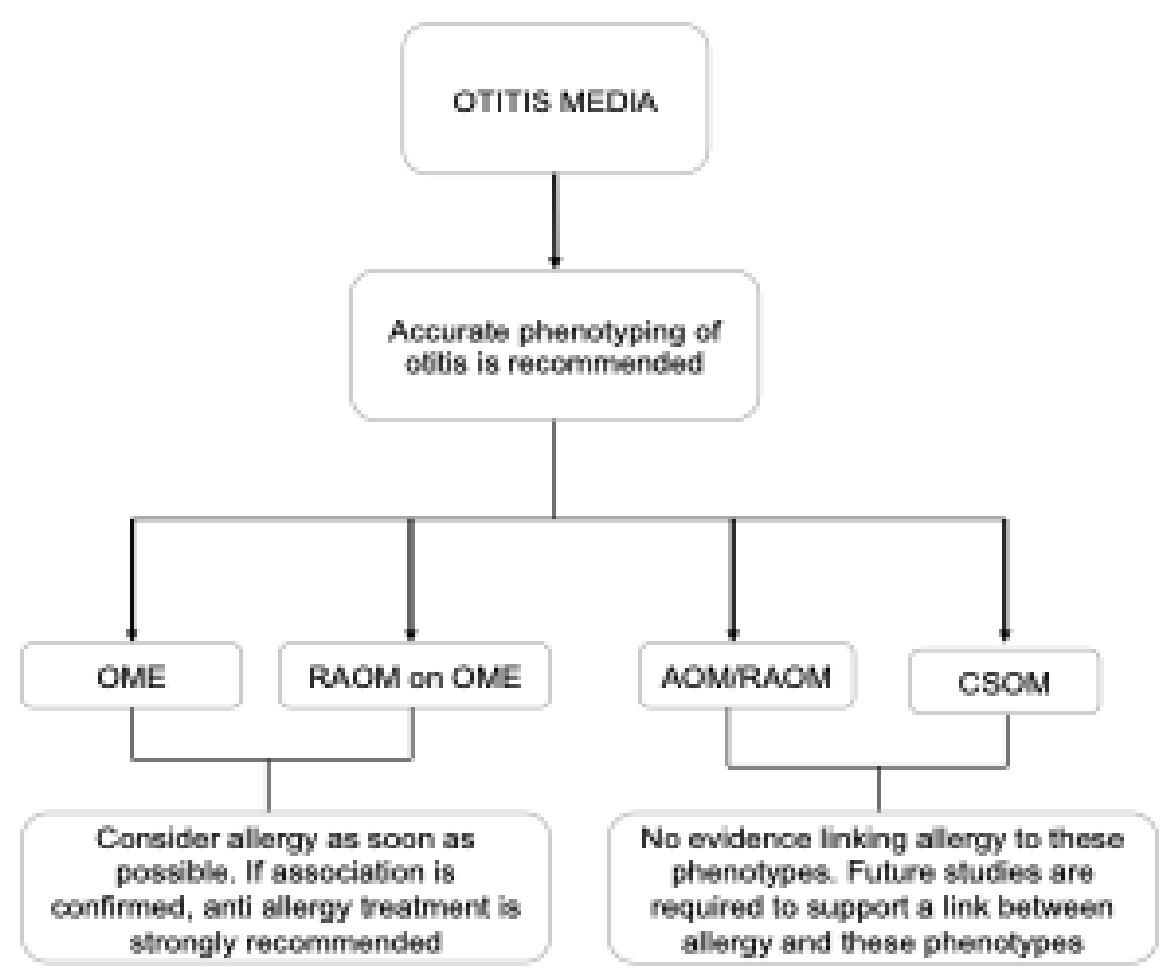

